\title{
Mechanisms mediating the stimulatory effects of the boar on gilt reproduction
}

\author{
P. E. Hughes, G. P. Pearce and A. M. Paterson* \\ Faculty of Agriculture and Forestry, University of Melbourne. Parkville, Victoria 3052, Australia; \\ and ${ }^{*}$ Department of Agriculture, Baron-Hay Court, South Perth, Western Australia 615l, Australia
}

Keywords: boar exposure; puberty; gilts; pheromones

The major stimulatory effects of boar presence on female pig reproduction are well documented. The boar can stimulate the early appearance of first oestrus in the prepubertal gilt, the lactating sow and the weaned sow. Additionally, boar presence may influence the exhibition and detection of oestrus, together with the sow's receptivity (see Hemsworth \& Barnett, 1990). Boar involvement in other aspects of sow reproduction such as the maintenance of cyclicity and pregnancy have also been postulated, although few research data are currently available. In this review the prepubertal gilt is used as the model for response of female pigs to boar stimuli, as most of the research data is to be found in this area.

Since the major boar effects have been known for some time it may appear surprising that the mechanism controlling them is not well understood. This may be partly due to the variation observed between studies in female response to boar contact, probably reflecting confounding factors such as genotype, climatic and housing environment, nutritional status and the age of the gilt. There is also evidence that the manner of boar exposure will influence the response of the female, since variations in the length and frequency of the exposure period and, possibly, the size of the exposure pen all affect the level of stimulation perceived by the female.

These interactions clearly influence the response of gilts to boar exposure. They therefore receive early attention in this review. The roles of individual components of the boar in gilt stimulation are then considered. Finally endocrine responses of gilts to boar exposure, or exposure to boar-component stimuli, are evaluated and a tentative mechanism of action of the boar effect is postulated.

\section{Non-boar factors influencing the efficacy of the boar effect}

The data presented in Table $!$ demonstrate that the pubertal response of the gilt to boar contact does not occur in a fixed-time period, even when the age of the gilt at the start of boar exposure is held constant. In most cases this is thought to be due to non-boar factors influencing the ability of the gilt to respond to boar stimulation. It is therefore pertinent to review these factors briefly in relation to boar-induced puberty in the gilt.

\section{Genotype}

Genetic influences on the natural attainment of puberty have been discussed in several recent reviews (Hughes, 1982; Christenson, 1986; Dyck, 1988). The relationship between genotype and boar-induced puberty attainment in gilts is, however, less well defined.

Between-breed differences in pubertal response to boar contact have been reported by several authors. While the extent of boar usage in these trials was variable, the consensus would be that Landrace gilts reach boar-induced sexual maturity earlier than do those of other breeds but that little difference is apparent amongst these other breeds (see Clark et al., 1970; Christenson \& Ford, 1979; Hutchens et al., 1982; Allrich et al., 1985). The same authors have also reported that heterosis 
Table 1. Variation in age at puberty in gilts exposed to mature boars

\begin{tabular}{|c|c|c|c|c|}
\hline Reference & Herd & $\begin{array}{l}\text { Average gilt } \\
\text { age at start of } \\
\text { boar contact } \\
\text { (days) }\end{array}$ & $\begin{array}{l}\text { Days of } \\
\text { puberty }\end{array}$ & $\begin{array}{l}\text { Age at } \\
\text { puberty } \\
\text { (days) }\end{array}$ \\
\hline Eastham et al. (1984) & Notlingham, UK & 160 & $7 \cdot 4$ & $166 \cdot 9$ \\
\hline Brooks \& Cole (1970) & Notlingham, UK & 165 & $7 \cdot 4$ & $172 \cdot 4$ \\
\hline Pearce (1982) & Notlingham. UK & 167 & $8 \cdot 4$ & $175 \cdot 0$ \\
\hline Easthàm et al. (1986b) & Nottingham, UK & 160 & $11 \cdot 3$ & $177 \cdot 3$ \\
\hline Kirkwood \& Hughes (1979) & Leeds, UK & 167 & $12 \cdot 0$ & $179 \cdot 0$ \\
\hline Paterson el al. (1989a) & Medina, Australia & 165 & $12 \cdot 7$ & $177 \cdot 0$ \\
\hline Paterson \& Lindsay (1981) & Medina, Australia & 160 & $15 \cdot 5$ & 177.0 \\
\hline Kirkwood \& Hughes (198I) & Leeds, UK & 160 & 18.8 & $182 \cdot 0$ \\
\hline Killian et al. (1987) & Missouri, USA & 155 & $20 \cdot 8$ & $191 \cdot 5$ \\
\hline Pearce \& Hughes (1987b) & Leeds, UK & 165 & $34 \cdot 2$ & $198 \cdot 0$ \\
\hline Kirkwood el al. (1981) & Leeds, UK & 160 & $47 \cdot 6$ & $207 \cdot 6$ \\
\hline Booth (1984b) & Cambridge, UK & 160 & $50 \cdot 0$ & $210 \cdot 0$ \\
\hline Paterson et al. (1989a) & Muresk, Ausıralia & 165 & $71 \cdot 7$ & $236 \cdot 8$ \\
\hline
\end{tabular}

is shown in the ability of gilts to respond to boar stimulation, although the actual reduction in pubertal age as a result of cross-breeding is not great.

Paterson et al. (1989a) observed large differences in gilt age at puberty in response to boar contact in two herds in which the selection policies were widely different. In the herd in which selection was based on growth performance mean pubertal age of gilts in response to daily boar contact from 165 days of age was 178 days. On the other hand, in Herd 2, for which the selection policy was based on litter size, gilts had a mean age at puberty in response to the same boar exposure regimen of 237 days. While some confounding factors relating to the climatic environment provided by these two herds were present, these results do suggest a possible influence of longterm selection policy on the ability of gilts to respond to boar stimulation. While this may reflect differences in gilt growth rate, and hence liveweight, at the start of boar exposure it may also indicate a negative genetic correlation between age at first farrowing and litter size (see Vangen, 1986).

\section{Nutrition}

The review of Aherne \& Kirkwood (1985) concluded that, while severe undernutrition of the young gilt could result in delayed puberty attainment, there was little evidence to support an inhibitory effect of mild dietary restriction on sexual maturation. Nevertheless, there is evidence to indicate that the gilt needs to attain threshold levels of liveweight before she is able to respond to puberty stimulation. For example, the study of King (1989) indicated that age at puberty increased linearly as liveweight of the gilt at boar introduction (170 days of age) was reduced. Furthermore, this result appears to be due to liveweight, rather than body fat content, since in a second experiment King (1989) reported that gilts with higher levels of body fat (at a given body weight) at 165 days of age tended to be later reaching puberty than their leaner counterparts.

Thus, any experimental protocol that includes either severe restriction of feed intake before puberty or boar contact from a very early age is likely to result in demonstrable nutritional influences on the ability of the gilt to respond to boar stimulation. The latter point is well illustrated by the study of Burnett et al. (1988), who reported that liveweight and backfat level exerted a decreasing influence on the ability of the gilt to respond to boar contact as gilt age at the start of this contact increased. Such results suggest that a higher proportion of gilts in the older age groups at first boar exposure are likely to have attained the necessary thresholds for liveweight and backfat, and hence are capable of responding to boar stimulation. 


\section{Climatic environment}

Many studies in the USA have compared gilt response to boar contact under 'confined' or 'non-confined' conditions (Christenson, 1981; Rampacek et al., 1981; Caton et al., 1986a). The results of these studies suggest that confinement may delay puberty attainment in gilts by approximately $4-7$ days.

Gilts housed in confined conditions may be less subject to seasonal temperature (and, possibly, photoperiod) fluctuations than are their non-confined contemporaries. Table 2 provides typical data relating season of boar exposure to puberty attainment in gilts, and indicates that the gilt tends to be more responsive to boar stimulation in the winter months. Furthermore, although the limited data that are available tend to be contradictory it appears likely that any seasonal effects that are operative exert a similar effect on both boar-induced and natural puberty attainment in gilts. However, exposure to boars partly overrides the depressive effects of season on gilt puberty (Table 3). Booth \& Baldwin (1983) reported that sows became acyclic over the summer after the removal of their olfactory bulbs. This observation, together with our work, would suggest that seasonat depressions in reproductive activity in female pigs may be overcome by providing olfactory stimulation from boars.

Table 2. The effects of season of boar exposure on puberty attainment in gilts

\begin{tabular}{|c|c|c|c|c|}
\hline \multirow[b]{2}{*}{ Reference } & \multirow{2}{*}{$\begin{array}{c}\text { Gilt age } \\
\text { at start of } \\
\text { boar contact } \\
\text { (days) }\end{array}$} & \multicolumn{3}{|c|}{ Gilt age at puberty (days) } \\
\hline & & Autumn/winter & Spring/summer & \\
\hline Mavrogenis \& Robison (1976) & 140 & $199 \cdot 3$ & 198.8 . & \\
\hline Rampacek et al. (1981) & iso & $221 \cdot 9$ & $236 \cdot 5$ & \\
\hline Christenson (1981)* & 146 & $(81 \cdot 3 \%)$ & $(75 \cdot 2 \%)$ & \\
\hline Cronin et al. (1983)! & 203 & $(91.4 \%)$ & $(91-2 \%)$ & $\cdot$ \\
\hline Paterson et al. (1989a) & & & & \\
\hline $\begin{array}{l}\text { Herd I } \\
\text { Herd } 2\end{array}$ & $\begin{array}{l}165 \\
165\end{array}$ & $\begin{array}{l}174 \cdot 5 \\
220 \cdot 5\end{array}$ & $\begin{array}{l}179 \cdot 9 \\
252 \cdot 5\end{array}$ & \\
\hline Paterson ef al. (1989b) & 175 & $186 \cdot 4$ & $203 \cdot 9$ & \\
\hline
\end{tabular}

* Percentage of gilts cyclic by 9 months of age.

†Percentage of gilts cyclic by 35 weeks of age. (This study involved 2484 gilts, and the data for individual seasons relating to the percentage of gilts cycling by 35 wceks of age were $90 \cdot 2,92 \cdot 1$, 93.7 and 88.8 for autumn, winter, spring and summer respectively.)

Table 3. Seasonal influences on puberty attainment in boar-exposed and non-boar-exposed gilts

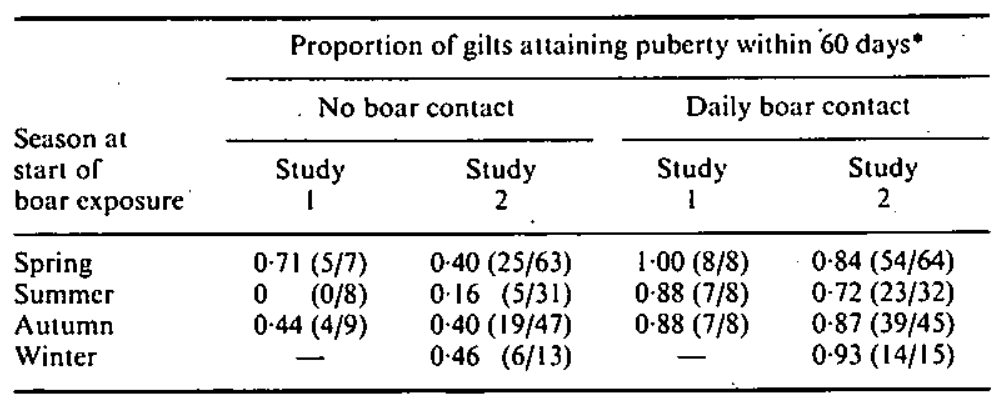

-Study I (Paterson et al., 1989b): cut-off age was 235 days.

Study 2 (A. M. Paterson \& G. P. Pearce, unpublished data): cut-ofl age was 225 days. 
Data relating the individual effects of photoperiod and temperature to the efficacy of the boar effect are limited. However, a study by Diekman \& Hoagland (1983) does suggest that photoperiod may influence gilt response to boar contact during periods of decreasing, but not increasing, natural daylength (Table 4).

Table 4. The effects of supplementary light on puberty attainment in boar-exposed and control gilts (no. in parentheses) (from Diekman \& Hoagland, 1983)

\begin{tabular}{lll}
\hline & \multicolumn{2}{c}{$\begin{array}{c}\text { Mean age at puberty of } \\
\text { responding gilts (days) }\end{array}$} \\
\cline { 2 - 3 } Treatment & $\begin{array}{c}\text { Increasing } \\
\text { daylength }\end{array}$ & $\begin{array}{c}\text { Decreasing } \\
\text { daylength }\end{array}$ \\
\hline $\begin{array}{c}\text { Control (no } \\
\text { supplementary light) }\end{array}$ & $200(13)$ & $199^{\circ b}(16)$ \\
$\begin{array}{c}\text { Control + } \\
\text { supplementary light }\end{array}$ & $213(15)$ & $197^{\circ b}(15)$ \\
$\begin{array}{c}\text { Boar exposure (no } \\
\text { supplementary light) } \\
\text { Boar exposure }+ \\
\text { supplementary light }\end{array}$ & $192(14)$ & $205^{\circ}(15)$ \\
\hline $\begin{array}{c}\text { Means in the same column } \\
\text { differ }(P<0.01) .\end{array}$ & $187(13)$ & $185^{b}(16)$ \\
\hline
\end{tabular}

The influence of ambient temperature on the gilt's ability to respond to boar stimulation is yet to be defined. To date all that can be stated is that extrapolation from studies such as that of Pearce \& Hughes (1985) tentatively suggests that high ambient temperatures may reduce the efficacy of the boar effect.

\section{Housing}

The relationships between housing and reproduction are dealt with in detail by Hemsworth \& Barnett (1990). It is, however, relevant to discuss the major interaction that housing conditions will have with boar-induced puberty attainment in gilts.

The effects of transport and other 'management stressors' (e.g. mixing and relocation) on boarinduced puberty in gilts have been adequately reviewed by Hughes (1982). Other housing variables are usually placed in the two categories of group size (number of gilts/pen) and stocking density. In these areas few research data are available to relate their effects to boar-induced puberty of gilts.

Data on the relationship between group size and the efficacy of the boar effect are extremely limited. Most studies confound the effects of group size and space allowance in relation to the boar effect (e.g. Mavrogenis \& Robison, 1976; Christenson \& Ford, 1979; Cronin et al., 1983; Hemsworth et al., 1986). Indeed, the only study that defines the roles of space allowance, group size and boar contact is that of Christenson (1984). The results of this work suggest that rearing gilts in groups of 3 .reduced the proportion of gilts cycling by 9 months of age relative to those females housed in groups of 9,17 or 27 per pen (proportions being $0.57,0.78,0.80$ and 0.81 respectively). A reduction in 'stimulatory interactions' between gilts is suggested as the cause of this reduced response in small groups of gilts (Christenson, 1984).

The study of Ford \& Teague (1978) reversed the conditions of the Christenson (1984) experiment by holding group size constant but varying the space allowance given to each gilt. Their results suggest that reducing the space allowance/gilt by 25 or $50 \%$ had little effect on the efficacy of 
the boar effect. However, it should be noted that the actual space allowances allocated were relatively low $\left(0.93,0.70\right.$ and $\left.0.47 \mathrm{~m}^{2} / \mathrm{pig}\right)$.

\section{Causes of variation in the efficacy of the boar effect}

The preceding discussion has briefly outlined some of the major genetic and environmental factors that may influence the efficacy of the boar effect. Variations in these factors, both between and within studies, certainly explain some of the inconsistency seen in gilt response to boar stimulation. The other causes of this variation in gilt response relate to the manner of boar exposure. In particular, the influences of the individual boar, the degree of contact allowed between boar and gilts, and the frequency and duration of boar contact must be considered.

\section{Between-boar variations}

A clear effect of boar age on the efficacy of boar-induced precocious puberty in gilts has been demonstrated by Kirkwood \& Hughes (1981). These authors suggested that boars may not be able to stimulate puberty attainment in the gilt until they reach an age of approximately 9-10 months. Zimmerman \& Kopf (1986) indicate that the 9-month-old boar may be as stimulatory as older boars and hence that boars are likely to achieve their full stimulatory ability at an age between 6.5 and 9 months.

Once boars have reached a sufficient age to exert full stimulating effect it is possible that between-boar variations may still exist in ability to induce precocious puberty in gilts. Such variations, should they exist, are likely to be related to either the level of pheromone release of the boar or his libido (see below). Unfortunately, no studies have yet been conducted to elucidate possible between-boar variations in stimulus effect. Casual observation suggests that the boar's libido level has little influence on his ability to induce early puberty attainment in gilts. Equally, while the known boar pheromones have been shown to increase in concentration with boar age (Booth, 1975), group rearing (Bonneau \& Desmoulin, 1980; Narendran et al., 1980) and copulation (Andresen, 1977; Claus, 1977), little is known concerning the relative stimulus value of mature boars ( 9 months of age and older) with different concentrations of pheromones in their blood or saliva. Of interest in this context is the study of Booth (1987) who compared the stimulating ability of Large White and Göttingen miniature boars, since the Göttingen boar is known to have concentrations of salivary pheromones 10 - to 20 -fold greater than those found in domestic boars (Booth, 1984a). The results of this study indicate that, despite its small stature, the Göttingen miniature boar is at least as stimulatory for puberty attainment in gilts as is the domestic boar (proportion of gilts responding to no boar exposure, or exposure to a Large White or a Göttingen miniature boar being $0,0.5$ and 0.75 respectively).

\section{Effects of full compared with restricted boar contact}

Early studies on the boar effect tended not to differentiate between full boar contact and the use of restricted or fence-line contact. More recent experiments have shown that fence-line contact is, in fact, far less effective as a puberty stimulation technique than is full physical contact with the boar (see Table 5). The common commercial practice of housing selected gilts in a pen adjacent to one or more mature boars is therefore unlikely to provide adequate puberty stimulation unless full physical contact with the mature boar is allowed on a daily basis (see below).

\section{Length of the daily exposure period to the boar}

In the review of Hughes (1982) the limited data available indicated that little or no difference in gilt pubertal response was apparent when boar contact was allowed on either a continuous or a 
Table 5. The effects of full and limited boar contact on puberty attainment in gilts

\begin{tabular}{|c|c|c|c|c|c|}
\hline Reference & $\underset{\substack{\text { Experimental } \\
\text { period }}}{ }$ & $\begin{array}{l}\text { Degree of } \\
\text { boar } \\
\text { contacl }\end{array}$ & $\begin{array}{l}\text { No. of } \\
\text { gilts }\end{array}$ & $\begin{array}{l}\text { Proportion } \\
\text { reaching } \\
\text { puberty }\end{array}$ & $\begin{array}{l}\text { Mean pubertal } \\
\text { age of } \\
\text { responding } \\
\text { gilts (days) }\end{array}$ \\
\hline $\begin{array}{l}\text { Karlbom } \\
\qquad(1981 / 2)\end{array}$ & $\begin{array}{c}142 \text { days } \\
-2 \text { nd oesirus }\end{array}$ & $\begin{array}{l}\text { None } \\
\text { Continuous fence line } \\
\text { Continuous fence line }+ \text { full } \\
\text { boar contact for } 20 \mathrm{~min} / \mathrm{day}\end{array}$ & $\begin{array}{l}19 \\
17 \\
17\end{array}$ & $\begin{array}{l}- \\
-\end{array}$ & $\begin{array}{l}198 \\
183 \\
163\end{array}$ \\
\hline $\begin{array}{l}\text { Deligeorgis et al. } \\
\text { (1984) }\end{array}$ & $156-210$ days & $\begin{array}{l}\text { None } \\
\text { Fence line for } 20 \mathrm{~h} / \text { day } \\
\text { Full for } 20 \mathrm{~h} / \text { day }\end{array}$ & $\begin{array}{l}21 \\
21 \\
21\end{array}$ & $\begin{array}{l}0.19 \\
0.38 \\
0.76\end{array}$ & $\begin{array}{l}191 \\
192 \\
168\end{array}$ \\
\hline $\begin{array}{l}\text { Caton el al. } \\
\quad(1986 \mathrm{~b})\end{array}$ & $180-210$ days & $\begin{array}{l}\text { Continuous fence line } \\
\text { Full contact for } 30 \mathrm{~min} / \text { day }\end{array}$ & $\begin{array}{l}20 \\
19\end{array}$ & $\begin{array}{l}0.10 \\
0.53\end{array}$ & $\begin{array}{l}199 \\
198\end{array}$ \\
\hline
\end{tabular}

Table 6. The effects of continuous and once-daily boar contact on puberty attainment in gilts

\begin{tabular}{|c|c|c|c|c|c|c|c|c|}
\hline \multirow[b]{2}{*}{ Reference } & \multirow{2}{*}{$\begin{array}{c}\text { Duration } \\
\text { of boar } \\
\text { contact } \\
\text { (days) }\end{array}$} & \multirow{2}{*}{$\begin{array}{l}\text { No. of } \\
\text { gilts/ } \\
\text { treatment }\end{array}$} & \multicolumn{3}{|c|}{ Proportion responding } & \multicolumn{3}{|c|}{ Mean days to puberty } \\
\hline & & & $\begin{array}{c}30 \mathrm{~min} / \\
\text { day }\end{array}$ & Continuous & Control & $\begin{array}{c}30 \mathrm{~min} / \\
\text { day }\end{array}$ & Continuous & Control \\
\hline Kirkwood \& & & & & & & & $a_{-}$ & \\
\hline $\begin{array}{l}\text { Hughes (1980a) } \\
\text { Van Lunen \& }\end{array}$ & $165-250$ & 10 & - & - & - & 34 & 30 & 67 \\
\hline $\begin{array}{l}\text { Aherne (1987) } \\
\text { Hemsworth }\end{array}$ & $140-150$ & 24 & 0.68 & 0.65 & 0.29 & 70 & 55 & 72 \\
\hline et al. (1988)* & $176-216$ & 16 & 0.93 & 0.81 & 0.31 & 13 & 19 & 30 \\
\hline
\end{tabular}

*The once-daily boar contact in this experiment was for 5 min only.

Table 7. The effects of length of daily boar exposure on the efficacy of the boar effect in gilts

\begin{tabular}{|c|c|c|c|c|c|}
\hline Reference & $\begin{array}{l}\text { Length of daily } \\
\text { boar exposure } \\
\text { period (min) }\end{array}$ & $\begin{array}{l}\text { No. of } \\
\text { gitts }\end{array}$ & $\begin{array}{l}\text { Age of } \\
\text { gilts } \\
\text { (days) }\end{array}$ & $\begin{array}{l}\text { Average } \\
\text { days to } \\
\text { puberty }\end{array}$ & $\begin{array}{l}\text { Proportion } \\
\text { responding }\end{array}$ \\
\hline $\begin{array}{l}\text { Caton et al. } \\
\text { (1986b) }\end{array}$ & $\begin{array}{r}5 \\
15 \\
30\end{array}$ & $\begin{array}{l}20 \\
20 \\
19\end{array}$ & $\begin{array}{l}180-210 \\
180-210 \\
.180-210\end{array}$ & $\begin{array}{l}16 \cdot 5 \\
13 \cdot 1 \\
20 \cdot 2\end{array}$ & $\begin{array}{l}0.40 \\
0.35 \\
0.53\end{array}$ \\
\hline $\begin{array}{l}\text { Paterson el al. } \\
\text { (1989b) }\end{array}$ & $\begin{array}{r}2 \\
10 \\
30\end{array}$ & $\begin{array}{l}13 \\
14 \\
13\end{array}$ & $\begin{array}{l}160-240 \\
160-240 \\
160-240\end{array}$ & $\begin{array}{r}24.9 \\
7.4 \\
11.7\end{array}$ & $\begin{array}{l}1.00 \\
0.71 \\
0.92\end{array}$ \\
\hline
\end{tabular}

$30 \mathrm{~min} /$ day basis. The subsequent studies of Van Lunen \& Aherne (1987) and Hemsworth et al. (1988) support this conclusion (see Table 6), suggesting that the necessary boar stimuli can be perceived by the gilt in a relatively short period of time. How little daily boar contact is actually necessary has been the subject of several recent studies. The results of this work (Table 7) suggest that a daily boar exposure period of $5-10 \mathrm{~min} /$ day may be adequate for gilt stimulation.

As discussed later the boar effect is considered to be due to a synergism between boar pheromones and the tactile/behavioural interactions associated with exposure to the boar. lt might therefore be expected that giving gilts boar contact for either a limited time each day or under conditions 
that allow avoidance of the boar (e.g. large exposure pen or a large group of gilts) may reduce the efficacy of the effect. In fact, in the only study conducted in this area little effect of either group size during boar exposure or the size of the test pen was seen when boar contact was allowed for 5 or $20 \mathrm{~min} /$ day (P. E. Hughes, unpublished data; Table 8). Interestingly, the results of this study indicate that $5 \mathrm{~min} /$ day of boar contact may be inadequate and hence that the above conclusion that $5-10 \mathrm{~min} /$ day is sufficient to maximize the boar effect is probably an underestimation.

Table 8. The effects of group size and test arena area on the efficacy of the boar effect

(P. E. Hughes, unpublished data)

\begin{tabular}{|c|c|c|c|c|c|c|}
\hline & \multicolumn{3}{|c|}{$20 \mathrm{~min} /$ day boar contact ${ }^{*}$} & \multicolumn{3}{|c|}{$5 \mathrm{~min} /$ day boar contact ${ }^{*}$} \\
\hline & $\begin{array}{l}\text { No. of } \\
\text { gilts }\end{array}$ & $\begin{array}{l}\text { Days to } \\
\text { puberty }\end{array}$ & $\begin{array}{l}\text { Proportion } \\
\text { responding }\end{array}$ & $\begin{array}{l}\text { No. of } \\
\text { gilts }\end{array}$ & $\begin{array}{l}\text { Days to } \\
\text { puberty }\end{array}$ & $\begin{array}{l}\text { Proportion } \\
\text { responding }\end{array}$ \\
\hline Test group size & & & & & $\cdot$ & \\
\hline 8 gilts & 16 & 12.9 & 0.87 & 16 & $24 \cdot 1$ & 0.87 \\
\hline 4 gilıs & 16 & $15 \cdot 3$ & 0.87 & 16 & 21.7 & 0.75 \\
\hline 2 gilts & 16 & $14 \cdot 0$ & 0.80 & 16 & $25 \cdot 6$ & 0.87 \\
\hline Test arena size & & & & & & \\
\hline Large & 24 & 13.7 & 0.86 & 24 & $23 \cdot 5$ & 0.79 \\
\hline Small & 24 & $14 \cdot 3$ & 0.83 & 24 & $24 \cdot 2$ & 0.87 \\
\hline
\end{tabular}

* Boar contact began at 160 days of age and continued for 40 days.

\section{Frequency of boar contact}

Studies in mice (Drickamer, 1987) have indicated that the efficacy of male-stimulated puberty in the female is more dependent on the regular reinforcement of stimuli from the male than the total time that the female is exposed to the male. This suggests that regular male exposure is a prerequisite for maximum stimulation of puberty in females.

Recent studies in Australia (Paterson et al., 1989a, b) were designed to test this hypothesis in the pig. The first of these experiments considered the efficacy of giving gilts boar contact for 0,1 or 10 days and compared these with a group of gilts given daily boar contact until puberty attainment. The results (Table 9) show that, while limited boar exposure does affect puberty attainment, gilts require the repeated stimulation provided by daily boar contact to maximize the boar effect. In a further study (Paterson et al., 1989b) puberty attainment was compared in groups of gilts receiving boar contact for $0,2,5$ or 7 days/week from 175 to 235 days of age. This experiment was conducted in 3 replicates at different times of the year and hence treatment results are to some extent confounded by season. However, the data (Table 10) do suggest that daily boar contact is necessary for maximum puberty stimulation in the young gilt.

\section{Number of boars used}

Many studies on the boar effect have used groups of boars to provide the necessary stimuli for gilt puberty. Unfortunately, little information has been provided on the relative efficacy of single boars and groups of boars. In an early report, Brooks \& Cole (1970) found that a weekly rotation of pairs of boars was more stimulatory to gilt puberty than was exposure to a single boar. However, these observations must be treated with caution as the gilts in the rotation group were not only exposed to a rotation of boars but also received daily contact with 2 boars and had additional fence-line contact with a further boar. More recently Kirkwood (1980) has reported little difference in the efficacy of the boar effect when applied using either a single boar or two boars on alternate days. The only other published data in this area are those of Van Lunen \& Aherne (1987).who 
Table 9. The effects of number of days, of boar contact on puberty attainment in the gilt (from Paterson et al., 1989a)

\begin{tabular}{|c|c|c|c|c|c|c|}
\hline \multirow[b]{2}{*}{$\begin{array}{l}\text { No. of days } \\
\text { of boar contact }\end{array}$} & \multicolumn{3}{|c|}{ Herd 1} & \multicolumn{3}{|c|}{ Herd 2} \\
\hline & $\begin{array}{l}\text { No. of } \\
\text { gilts }\end{array}$ & $\begin{array}{l}\text { Average } \\
\text { days to } \\
\text { puberty }\end{array}$ & $\begin{array}{l}\text { Proportion } \\
\text { respondingt }\end{array}$ & $\begin{array}{l}\text { No. of } \\
\text { gilts }\end{array}$ & $\begin{array}{l}\text { Average } \\
\text { days to } \\
\text { puberty }\end{array}$ & $\begin{array}{l}\text { Proportion } \\
\text { respondingt }\end{array}$ \\
\hline 0 & 17 & 51.4 & 0.65 & 14 & 105.8 & .0 .43 \\
\hline 1 & 17 & $41 \cdot 5$ & 0.76 & 15 & 95.4 & 0.47 \\
\hline 10 & 16 & $28 \cdot 5$ & 0.81 & 15 & 84.7 & 0.67 \\
\hline Daily & 15 & $12 \cdot 7$ & 1.00 & 14 & $71 \cdot 7$ & 0.86 \\
\hline
\end{tabular}

*Starting at a gilt age of 165 days.

†Gilts reaching puberty by 245 days of age (Herd 1) or 300 days of age (Herd 2).

Table 10. The influence of frequency of boar contact on the efficacy of the boar affect (from Paterson et al., 1989b)

\begin{tabular}{|c|c|c|c|c|}
\hline \multirow[t]{2}{*}{ 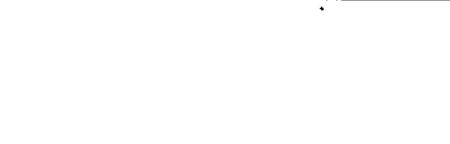 } & \multicolumn{4}{|c|}{$\begin{array}{l}\text { Frequency of boar exposure } \\
\text { (days/week) }\end{array}$} \\
\hline & 0 & 2 & 5 & 7 \\
\hline \multicolumn{5}{|l|}{ January } \\
\hline Mean intervals to puberty (days) & $\cdot-$ & 36.4 & $34 \cdot 3$ & $28 \cdot 7$ \\
\hline Proportion reaching puberty & $0 / 8$ & $7 / 8$ & $7 / 8$ & $7 / 8$ \\
\hline \multicolumn{5}{|l|}{ May } \\
\hline Mean intervals to puberty (days) & $48 \cdot 0^{n}$ & $32 \cdot 6^{b}$ & $33 \cdot 8^{b}$ & $11 \cdot 4^{\mathrm{c}}$ \\
\hline Proportion reaching puberty & $4 / 9$ & $8 / 9$ & $8 / 8$ & $7 / 8$ \\
\hline \multicolumn{5}{|l|}{ October } \\
\hline Mean intervals to puberty (days) & $44 \cdot 6^{2}$ & $32 \cdot 3^{b}$ & $18 \cdot 4^{c}$ & $16 \cdot 5^{\circ}$ \\
\hline Proportion reaching puberty & $5 / 7$ & $7 / 8$ & $8 / 8$ & $8 / 8$ \\
\hline
\end{tabular}

indicated that the use of groups of boars may even reduce the stimulatory value of the boar effect when compared with the efficacy of single boar exposure. These authors suggested that the interactions occurring between boars in the multiple-boar exposure treatment may have frightened the gilts, resulting in boar avoidance or, at least, less frequent interactions between boars and gilts.

\section{Effects of early boar contact}

Most research studies have used the daily introduction of a mature boar to young gilts once they reach $150-170$ days of age: However, this initial contact with a boar may not be novel to the gilts since they are likely to be reared in contact with castrated or entire male contemporaries. Such a rearing regimen has been suggested to be inhibitory to sexual maturation in response to mature boar contact, possibly because gilts become habituated to boar-originating stimuli (Brooks \& Cole, 1969).

Experiments conducted at the University of Nottingham and elsewhere have documented that housing the young gilt in alt female or mixed sex (with castrates or entire male contemporaries) groups has little or no influence on the pubertal response of the gilt to contact with a mature boar from 160 days of age (Paterson \& Lindsay, 1980; Cole et al., 1982). Furthermore, housing gilts from 
70 to 160 days of age in fence-line contact with a mature boar has little or no effect on the response of gilts to subsequent full boar exposure at 160 days of age (Eastham et al., 1986a), even when the same boar is used throughout (Eastham \& Cole, 1987).

However, all the above experiments utilized relocation of gilts at 160 days of age in addition to the start of exposure to a mature boar at this time. Eastham \& Cole (1987) allowed fence-line contact for gilts with a mature boar from 70 to 160 days of age and then relocated the gilts or left them in their original accommodation. Subsequently, the gilts received daily full boar contact with a different mature boar. The results of this study clearly demonstrated that, under these conditions, relocation was an important component of the boar effect, since relocated gilts reached puberty significantly earlier than did their non-relocated counterparts (Table 11). This suggests that the 'stress' of relocation is required for the full boar effect to be shown when contact with a mature boar does not constitute a novel experience.

Table 11. Puberty attainment in gilts reared in fence-line contact with a mature boar and subsequently given exposure to a novel mature boar cither alone or in conjunction with relocation at 160 days of age (from Eastham \& Cole, 1987)

\begin{tabular}{|c|c|c|c|}
\hline & $\begin{array}{l}\text { Novel boar } \\
\text { only }\end{array}$ & $\begin{array}{c}\text { Novel boar }+ \\
\text { relocation }\end{array}$ & Significance \\
\hline No. of gilts & 31 & 32 & \\
\hline $\begin{array}{l}\text { Proportion of gilts reaching } \\
\text { puberty by } 210-213 \text { days of } \\
\text { age }\end{array}$ & 0.39 & 0.78 & $P<0.001$ \\
\hline $\begin{array}{l}\text { Mean inter:. from start of } \\
\text { treatment to puberty (days) }\end{array}$ & $89 \cdot 3$ & $20 \cdot 2$ & $P<0.001$ \\
\hline
\end{tabular}

\section{Components of the boar effect}

To understand how the boar effect works it is necessary to elucidate those components of boar exposure that have a stimulatory value in terms of accelerated gilt maturation. The boar himself may be seen as constituting four possible stimulatory components, these being visual, auditory, tactile and olfactory cues. In addition, the actual process of taking gilts to a boar for stimulation must be considered since this is usually involved in the application of the boar effect.

\section{Daily movement}

The studies of Kirkwood \& Hughes (1980b) and Pearce \& Hughes (1985) suggest that a daily pen change is slightly stimulatory for gilt puberty relative to control animals, but that the degree of stimulation is considerably less than that afforded by a pen change plus boar exposure (Table 12). It is therefore not surprising that the pubertal response of the gilt to boar contact tends to be better when exposure occurs in the boar's pen rather than the home pen of the gilts (Table 13). Furthermore, it was suggested by Kirkwood \& Hughes (1980b) that conducting the boar exposure test in the boar pen would not only provide the gilts with the stimulus of daily movement but would also allow exposure to an accumulation of boar pheromones within that pen. However, the more recent study of Pearce \& Hughes (1985) did not show any advantage of exposing gilts in the boar pen over exposure in a 'new' pen cleaned daily. 
Table 12. The relative effects of daily pen change and boar exposure on puberty attainment in gilts

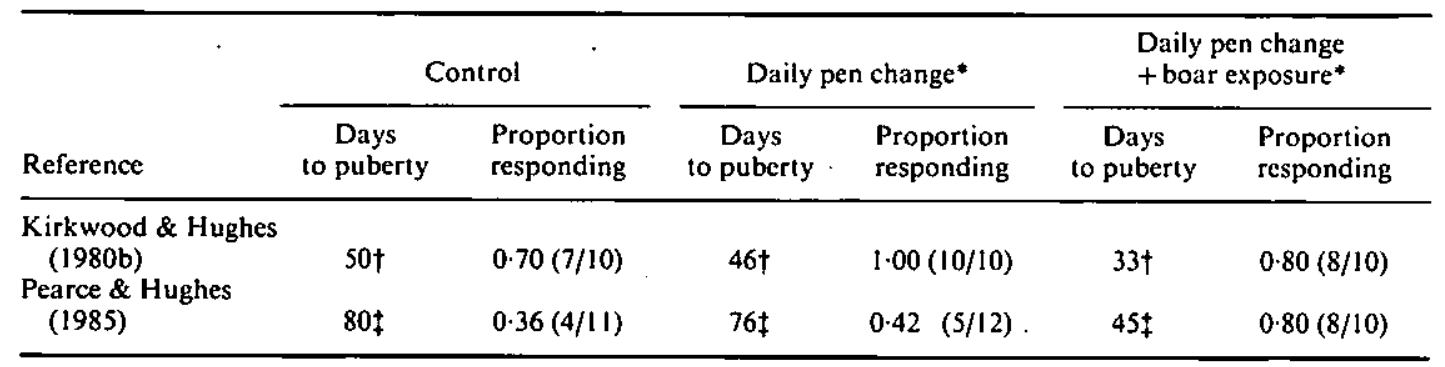

*Treatments began at a mean gilt age of 165 days.

tMean.

$\ddagger$ Median.

Table 13. The stimulus value of the boar effect for trials conducted in the pen of the gilt or the boar

\begin{tabular}{lcccc}
\hline & \multicolumn{4}{c}{ Proportion of gilts responding* } \\
\cline { 2 - 5 } Reference & $\begin{array}{c}\text { No. of gilts/ } \\
\text { treatment }\end{array}$ & Control & $\begin{array}{c}\text { Boar taken } \\
\text { to gilts }\end{array}$ & $\begin{array}{c}\text { Gilts taken } \\
\text { to boar }\end{array}$ \\
\hline Scheimann et al. (1976) & $16-25$ & 0.31 & 0.46 & 0.78 \\
Van Lunen \& Aherne (1987) & 24 & 0.29 & 0.48 & 0.68 \\
\hline
\end{tabular}

* Response was measured for 17 days, from a mean gilt weight of $85 \mathrm{~kg}$, by Scheimann et al. (1976) and for 130 days, from a gilt age of 140 days, by Van Lunen \& Aherne (1987).

\section{Visual cues}

It is difficult to reproduce exactly the visual appearance of a boar without providing some of the other boar-originating cues such as auditory and tactile stimulation. In view of this the studies that have been performed have used either castrated or long-term androgenized castrated males. The mature castrated male is likely to be similar to a mature boar in appearance, although it will, of course, lack testes and exhibit some differences in tissue distribution in the body. On the other hand the androgenized castrate should more closely resemble the appearance of the intact male, but is also likely to exhibit 'normal' entire-male behaviour (tactile cues) and, possibly, emit 'normal' auditory cues (Booth, 1980).

In an early study by Kinsey et al. (1976) it was suggested that contact for prepubertal gitts with a castrated male provided as effective a stimulation to puberty as exposure to an intact boar. This would indicate that the visual component of the boar was of primary importance in the boar effect. However, Pearce \& Hughes (1987b) clearly demonstrated that visual cues presented by a castrated male without other exogenous boar stimuli were considerably less effective in stimulating gilt puberty than were the full range of boar-originating cues offered by an entire boar (see Table 14).

\section{Auditory cues}

Few definitive data are available on the role of auditory cues in the boar effect. Once again the study of Kinsey et al. (1976) indicates that the provision of auditory cues (recorded boar chants in isolation) is equivalent to contact with a mature boar for puberty stimulation in the gilt.. In contrast, Pearce \& Hughes (1987b) suggest that auditory stimuli are, at most, a minor part of the boar effect (Table 14). Indeed, these latter studies failed to find a significant change in either the.proportion of gilts responding to stimulation or gilt age at puberty. when a recording of boar chants was added to exposure to a long-term androgenized castrate male. 
Table 14. The effect of boar visual, auditory and olfactory stimuli on puberty attainment in gilts (adapted from Pearce \& Hughes, 1987b)

\begin{tabular}{|c|c|c|c|c|}
\hline \multirow[b]{2}{*}{$\begin{array}{l}\text { Boar component stimuli } \\
\text { provided }\end{array}$} & \multicolumn{2}{|c|}{ Experiment 1} & \multicolumn{2}{|c|}{ Experiment 2} \\
\hline & $\begin{array}{l}\text { Median days } \\
\text { to puberty }\end{array}$ & $\begin{array}{l}\text { Proportion } \\
\text { responding* }\end{array}$ & $\begin{array}{l}\text { Median days } \\
\text { to puberty }\end{array}$ & $\begin{array}{l}\text { Proportion } \\
\text { responding* }\end{array}$ \\
\hline Visual + tactile & $68 \cdot 0^{\text {ne }}$ & $0.76(13 / 17)$ & - & - \\
\hline Visual + tactile + auditory & $67.5^{\circ}$ & $0.56(10 / 18)$ & $66 \cdot 0^{*}$ & $0.58 \quad(7 / 12)$ \\
\hline $\begin{array}{l}\text { Visual + tactile + auditory } \\
\quad+\text { androstenes }\end{array}$ & $58 \cdot 5^{\circ}$ & $0.78(14 / 18)$ & 一 & - \\
\hline $\begin{array}{l}\text { Visual + tactile + auditory } \\
\text { + urine }\end{array}$ & 一 & - & $49 \cdot 0$ & $0.75(9 / 12)$ \\
\hline $\begin{array}{l}\text { Visual + tactile + auditory } \\
\quad+\text { androstenes + urine }\end{array}$ & - & - & $39 \cdot 0$ & $0.78 \quad(7 / 9)$ \\
\hline Entire boar & $35 \cdot 5^{\text {bd }}$ & $0.89(16 / 18)$ & $33 \cdot 0^{6}$ & $.1 .00(11 / 11)$ \\
\hline
\end{tabular}

*By 240 days of age.

Within columns a is b means are significantly different $(P<0.05)$; $\mathrm{c}$ ws d means are significantly different $(P<0.01)$.

\section{Tactile cues}

It is difficult to define what is meant by tactile cues in the context of the boar effect. Essentially, it is a term used to describe any physical interaction between boar and gilts, and may therefore refer to both casual contact and full courtship behaviour. It is not possible to provide such tactile cues in isolation since they must be associated with an active boar, i.e. visual, and possibly auditory and olfactory stimuli will also be provided. The androgenized castrate male certainly provides both visual and tactile cues (see Pearce \& Hughes, 1987b), but appears to be relatively ineffective in stimulating early puberty attainment in the gilt (Table 14).

Conversely, when prepubertal gilts are given access to visual, auditory and olfactory stimuli from the boar but are denied full physical contact (i.e. fence-line contact is used) little puberty stimulation is evident (Table 5). It therefore appears that boar-originating tactile cues are not, on their own, major stimulants for gilt puberty, but that entire boars are also of low stimulus value if they are denied the opportunity to utilize tactile stimulation. This suggests that tactile cues act either additively or synergistically with other boar-originating cues. Indeed, since the long-term androgenized castrate, when used with a recording of boar chants, is unable to significantly advance puberty attainment this strongly suggests that tactile cues from the boar act in concert with olfactory stimuli.

\section{Olfáctory cues}

The preceding discussion indicates that neither daily movement nor visual, auditory and tactile stimuli from the boar is the primary component of the boar effect. Thus, by elimination we must conclude that the boar produces an olfactory stimulus (primer pheromone) that will alter the endocrine status of the prepubertal gilt. This conclusion was verified by the study of Kirkwood et al. (1981) when gilts from which the olfactory bulbs had been excised were shown to be unresponsive to boar stimulation.

This raises the question as to the identity of the pheromones involved. The two known boar pheromones ( $5 \alpha$-androstenone and $3 \alpha$-androstenol) are principally found in the urine and saliva of boars, and are.recognized to have signalling pheromone properties (Reed $e t$ al., 1974). Kirkwood $e t$ al. (1983) and Booth (1984b) reported that neither of these pheromones was very effective on their own or in combination for stimulating gilt puberty (Table 15). However, there was an indication in the studies of Kirkwood et al. (1983) that $3 \alpha$-androstenol may have some role in the boar effect. 
The major site of release of this pheromone is in the frothy saliva secreted by the submaxillary salivary glands of the boar in response to sexual arousal (Booth, 1980; Perry et al., 1980). Since the serous cells of these glands undergo hypertrophy at a boar age between approximately 8 and 10 months (i.e. it is at this time that they begin to accumulate appreciable amounts of $3 \alpha$-androstenol), a role for this pheromone in the boar effect would explain the inability of young boars to stimulate early puberty in gilts (see abóve).

To study submaxillary salivary gland pheromone involvement in the boar effect, Pearce et al. (1988) compared the ability of boars to stimulate gilt puberty after the removal of these glands. Their results indicate that the sialectomized boar is significantly less effective in stimulating gilt puberty than is the unoperated boar, but that a boar lacking only the submaxillary salivary gland pheromones still has some stimulatory effect on the prepubertal gilt (median intervals to puberty for control, sialectomized boar and unoperated boar exposure groups were 64, 39 and 16 days respectively). This may indicate that the non-olfactory stimuli provided by the boar do initiate a degree of sexual development in the gilt, but that this is considerably less than that afforded by an intact boar releasing salivary pheromones. Alternatively, pheromones released from sites other than the submaxillary salivary glands (e.g. urine) may be involved in the boar effect (see Table 14).

Table 15. The effects of isolated boar pheromones on puberty attainment in the gilt

\begin{tabular}{|c|c|c|c|}
\hline & \multicolumn{3}{|c|}{ Proportion of gilts reaching puberty* } \\
\hline & \multicolumn{2}{|c|}{ Kirkwood et al. (1983) } & \multirow[b]{2}{*}{ Booth $(1984 b)$} \\
\hline & Trial 1 & Trial 2 & \\
\hline Control & $0.25(2 / 8)$ & - & $0.17(1 / 6)$ \\
\hline 5a-Androstenone & $0.25(2 / 8)$ & $0.12(1 / 8)$ & - \\
\hline $3 \alpha$-Androstenol & $0.50(4 / 8)$ & $0.38(3 / 8)$ & - \\
\hline \multirow{3}{*}{$\begin{array}{l}\text { 5a-Androstenone }+3 \alpha \text {-androstenol } \\
5 \alpha \text {-Androstenone }+3 \alpha \text {-androstenol } \\
\quad+\text { saliva } \\
\text { Boar exposure }\end{array}$} & $0.38(3 / 8)$ & $0.25(2 / 8)$ & - \\
\hline & - & - & $0.33(2 / 6)$ \\
\hline & - & $1 \cdot 00(7 / 7)$ & $1.00(6 / 6)$ \\
\hline
\end{tabular}

At this stage it is clear that neither boar-originating pheromones in isolation nor contact with non-pheromone producing boars is an effective stimulus to gilt puberty. This implies that boar pheromones act synergistically with the boars' non-olfactory stimuli to elicit the full boar effect. To study this relationship Pearce \& Hughes (1987b) provided the two known pheromones on carrier animals (long-term androgenized castrated boars). In addition, since the carrier animals would also provide the visual and tactile cues of the boar, the experiment was conducted in the presence or absence of exogenous boar-originating auditory stimulation. The results of these studies (Table 14) suggested that the provision of the visual, auditory, tactile and known olfactory boar-originating stimuli was sufficient to mimic the puberty-stimulating effect of an entire boar in those gilts that perceived the stimuli. Failure to perceive the boar-originating stimuli by some gilts may have been due, in part, to the provision of the boar pheromones in the absence of their binding protein (pheromaxein: Booth \& White, 1988), although the use of boar saliva in association with $3 a$ androstenol and $5 \alpha$-androstenone (but in the absence of a carrier animal) has not proved to be an effective puberty stimulant in the gilt (Booth, 1984b).

In summary, the current state of knowledge suggests that the boar effect operates via a synergistic action of several boar component stimuli. These include salivary and urinary pheromones (both identified and non-identified), tactile cues and, possibly, visual and auditory stimuli. 


\title{
Mechanisms of action of the boar effect
}

At this point it would be ideal to relate the foregoing discussion to an endocrine mechanism for puberty attainment in the gilt. Unfortunately, the endocrine events leading to puberty attainment in the female are incompletely understood, even in those laboratory animals towards which most of the research effort has been directed. Nevertheless, many of the hormonal changes that occur in the prepubertal gilt can now be explained and a tentative scheme for sexual development may be outlined.

\section{Endocrine development in the prepubertal period}

Attainment of puberty in the gilt is normally defined as the time of first ovulation (Hughes, 1982; Paterson, 1982). The major endocrine changes occurring in the immediate prepubertal period that result in this ovulation are reasonably well documented (Karlbom et al, 1981/2; Esbenshade et al., 1982; Andersson et al., 1983; Camous et al., 1985), and may be represented as follows:

\author{
Rising oestrogen concentrations \\ 1 \\ Threshold levels initiate stimulatory \\ oestrogen feedback to the hypothalamus \\ $\downarrow$ \\ Preovulatory surge of LH \\ $\downarrow$ \\ First ovulation, accompanied by \\ behavioural oestrus, i.e. attainment of puberty
}

These changes are equivalent to endocrine profiles seen during the follicular phase of cyclic gilts (Esbenshade et al., 1982). However, while the stimuli that initiate this follicular phase during the oestrous cycle are relatively well understood (Foxcroft \& van de Wiel, 1982), this is not the case in the prepubertal gilt.

Since rising oestrogen concentrations imply that follicular growth is occurring, the most obvious stimulus for the gilt to enter this pro-oestrous phase would be an increase in gonadotrophin secretion. Such a change could be brought about by one or more of the following developmental changes:

(1) a reduction in the sensitivity of the hypothalamic-pituitary unit to the inhibitory effects of oestradiol, i.e. the gonadostat theory (Ramirez \& McCann, 1963; Grumbach et al., 1974);

(2) a reduction in the relative metabolic clearance rate of oestrogens (Elsaesser et al., 1982; Christenson et al., 1985);

(3) increased GnRH output from the hypothalamus (Lutz et al., 1985);

(4) increased pituitary sensitivity to GnRH (Elsaesser \& Smidt, 1986).

Alternatively, it has also been proposed that plasma oestrogen concentrations may rise as a result of changes in ovarian gonadotrophin receptors and/or steroidogenesis (Suzuki et al., 1978; SmithWhite \& Ojeda, 1981; Meijs-Roelofs et al., 1983). A further possibility is that a change occurs in the pattern of LH secretion such that, while the mean plasma concentration of this hormone remains unchanged, the pulse frequency increases and pulse amplitude decreases (Diekman et al., 1983; Lutz et al., 1984; Elsaesser \& Smidt, 1986). The fact that either pulsatile administration of GnRH (Lutz et al., 1985; Carpenter \& Anderson, 1985) or exogenous LH (Huff \& Esbenshade, 1988) is capable of stimulating precocious puberty in gilts would indicate that the final developmental event leading to onset of puberty occurs at the level of the hypothalamus.

The limited data available on endocrine profiles in the gilt during the weeks leading up to puberty attainment preclude the drawing of firm conclusions regarding the mechanisms that 


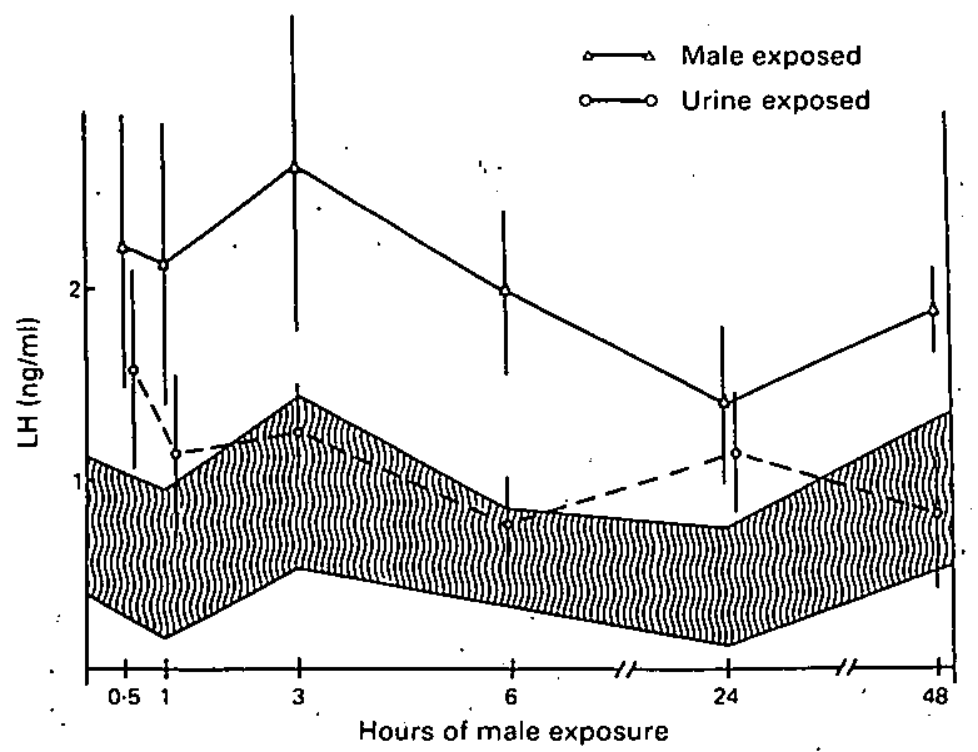

Fig. 1. Mean ( \pm s.e.; $140-160$ females/treatment) concentrations of serum LH in immature female mice exposed to male urine or to the presence of an intact male (from Bronson \& Maruniak, 1976). The shaded area indicates the mean \pm s.e. for isolated controls.

initiate the first follicular phase, and hence puberty. Most reports suggest that the gilt is in a 'plateau' phase at this time, having low circulating concentrations of both gonadotrophins and oestradiol (Karlbom et al., 1981/82; Andersson et al., 1983; Diekman et al., 1983), although the results of Lutz et al. (1984) indicated that plasma LH values may rise as early as 12 days before the gilt attains puberty. In addition, Camous et al. (1985) reported that oestrogen secretion may increase over a period of several weeks before attainment of puberty.

\section{Endocrine responses of the gilt to boar contact}

Paterson (1982) reviewed the known endocrine responses of gilts to boar contact and concluded that boars stimulate puberty in gilts by effecting a rise in oestradiol concentrations. What could not be determined at the time was the sequence of endocrine events that caused this elevation in plasma oestradiol values.

Studies on the male effect in rodents have revealed that male contact causes a rise in basal LH concentrations in the female (Bronson \& Desjardins, 1974; Bronson \& Maruniak, 1976): This is followed by a period of elevated plasma oestradiol concentrations that may last for as long as 2 days, and is thought to trigger a positive feedback response resulting in the preovulatory surge in gonadotrophin secretion. A similar LH response to male contact has also been reported in the ewe (Martin et al., 1980).

Most studies of the gilt have failed to detect a significant change in the pattern of LH secretion in response to boar contact, although raised oestradiol concentrations have been observed (Paterson et al., 1980; Esbenshade et al., 1982; Andersson et al., 1983). It is possible that a subtle change in LH concentrations may be induced by boar contact, or that changes occur in the magnitude and/or frequency of tonic LH release. The latter suggestion is supported by the work of Lutz et al. (1984) and would indicate an endocrine response to male contact similar to that seen in the ewe (Martin et al., 1980; Poindron et al., 1980). Such changes are difficult to detect in the gilt since normal circulating concentrations are extremely low and the interval from first boar contact 


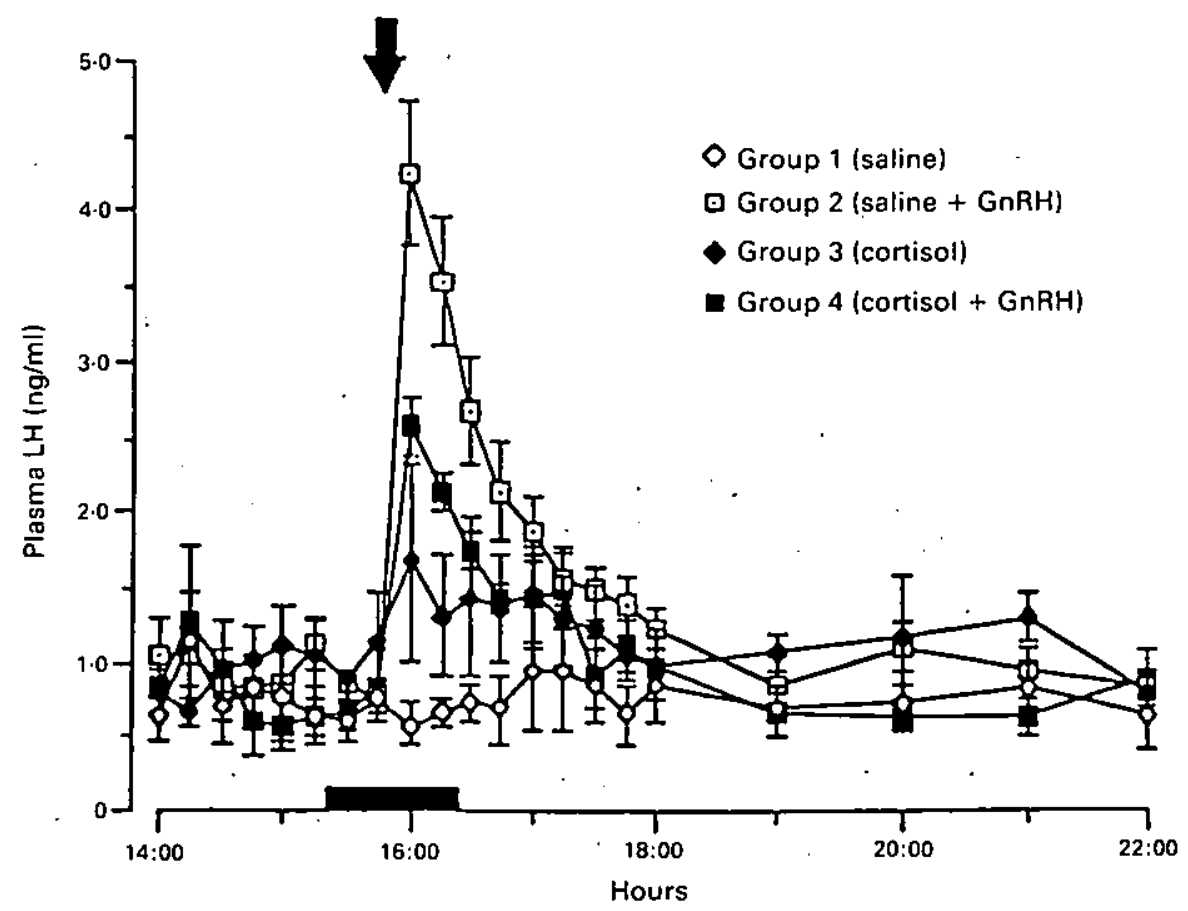

Fig. 2. The effects of cortisol infusion (horizontal bar) and GnRH administration (arrow) on LH secretion in the prepubertal gilt. Values are means \pm s.e.m. for 6 gilts/group. (From Pearce .. et al., 1988.)

to puberty is so variable. The latter point is particularly relevant since it creates uncertainty as to when to impose a regimen of frequent blood collection to determine endocrine responses.

Exposure of prepubertal female rodents to male urine (the source of the primer pheromone in these species) in the absence of the male results in a reduced pubertal response (Bronson \& Maruniak, 1975) and an abated LH response (Bronson \& Maruniak, 1976; Fig. 1). Bronson \& Maruniak (1976) also suggested that the role of the tactile cues from the males was to enhance the $\mathrm{LH}$ response of the females to male pheromones.

The tactile stimulation involved in boar contact is associated with an acute release of cortisol in the gilt (Pearce \& Hughes, 1987a). This response is also seen when pigs are transported (Barnett $e t$ al., 1984), relocated (Wodzicka-Tomaszewska et al., 1985) or mated (Barnett $e t$ al., 1982). Since a similar response can be obtained when gilts are exposed to a long-term androgenized castrated boar, this effect is clearly independent of olfactory stimulation (Pearce \& Hughes, 1987a).

Whether or not this acute elevation in cortisol concentrations in response to boar exposure plays a role in boar-induced precocious puberty in gilts is equivocal. However, the fact that the removal of the tactile component from boar exposure (by using fence-line contact) reduces the efficacy of the boar effect strongly suggests that acute cortisol release may be a component of overall boar stimulation.

The interactions that occur between plasma cortisol and the gonadotrophic hormones appear to be complex. The fact that adrenalectomy reduces the pubertal response of gilts to boar exposure (Killian et al., 1987) and to PMSG/hCG treatment (Killian et al., 1983) suggests a stimulatory role for adrenal function in puberty attainment in the gilt. On the other hand, several studies have indicated that the administration of cortisol or ACTH decreases pituitary responsiveness to exogenous GnRH (Barb et al., 1982; Fonda et al., 1984; Pearce et al., 1988). However, while acutely elevated cortisol concentrations reduced pituitary release of LH in response to exogenous GnRH 
administration, they appeared to increase basal LH secretion (Li, 1987; Pearce et al., 1988; Fig. 2). This elevation in basal LH levels may be associated with the commencement of follicular development and hence represent the important physiological response of the gilt to the tactile cues emanating from the boar.

Our current state of knowledge is insufficient to allow a full mechanism of action of the boar effect to be derived from the foregoing discussion. Nevertheless, a tentative scheme of endocrine responses to the boar may be suggested.

(1) Boar pheromones may alter the pattern of LH secretion in the gilt (yet to be demonstrated).

(2) The release of cortisol accompanying full boar contact further alters the secretory pattern of LH and/or physical contact with the boar enhances the transfer of primer pheromones.

(3) These alterations in LH secretion stimulate follicular development and result in an elevation of plasma oestradiol concentrations.

(4) The oestradiol stimulatory feedback system is triggered, resulting in the first preovulatory LH surge and thus the pubertal ovulation.

\section{Conclusions}

Our knowledge of the boar effect has been expanded to encompass its interactions with other factors that affect puberty attainment and those variations in its application that influence its efficacy. Furthermore, it is now established that the stimuli emanating from the boar are in two categories, namely olfactory and tactile/stress cues.

The endocrine basis of the boar effect remains obscure. While raised oestradiol concentrations are considered to be a consequence of boar exposure, other hormonal responses have yet to be consistently demonstrated. It is clear that the endocrine stimulus for follicular development, and hence oestradiol secretion, needs to be identified. Furthermore, the relationship between this stimulus and boar-originating cues must be established.

\section{References}

Aherne, F.X. \& Kirkwood, R.N. (1985) Nutrition and sow prolificacy. J. Reprod. Fert.. Suppl. 33, 169-183.

Allrich, R.D., Christenson, R.K. \& Ford, J.J. (1985) Age at puberty and estrous activity of straightbred and reciprocal crossbred gilts. Anim. Reprod. Sci. 8, $281-286$.

Andersson, A.-M., Einarsson, S. \& Edqvist, L.-E. (1983) Prcpubertal LH, oestradiol-17\% and progesterone pattern in gilts. Zentbl. VetMed. A 30, 438-446.

Andresen, O. (1977) 5-androstenone and testosterone in peripheral plasma of the boar during and following copulation. Anim. Br. Abstr. 45, 284, abstr.

Barb, C.R., Kraeling, R.R., Rampacek, G.B., Fonda, E.S. \& Kiser, T.E. (1982) Inhibition of ovulation and L.H secretion in the gilt after treatment with ACTH or hydrocortisone. J. Reprod. Fert. 64, 85-92.

Barnett, J.L., Hemsworth, P.H. \& Cronin, G.M. (1982) The effect of mating on plasma corticosteroids in the female pig and the influence of individual and group penning on this response. Gen. comp. Endocrinol. 47, 516-521.

Barnett, J.L., Cronin, G.M., Hemsworth, P.H. \& Winfield, C.G. (1984) The welfare of confined sows: physiological, behavioural and production responses to contrasting housing systems and handler attitudes. Alnhls Rech. vet. 15, 217-226.
Bonneau, M. \& Desmoulin, B. (1980) Evaluation de la teneur en androstenone du tissu adipeux dorsal chez la porc male entier de type Large White: variations selon les conditions d'elevage. Reprod. Nutr. Develop. 20, 1429-1437.

Booth, W.D. (1975) Changes with age in the occurrence of C19 steroids in the testis and submaxillary gland of the boar. J. Reprod. Fert. 42, 459-472.

Booth, W.D. (1980) A study of some major testicular steroids in the pig in relation to their effect on the development of male characteristics in the prepubertally castrated boar. J. Reprod. Fert. 59, 155-162.

Booth, W.D. (1984a) Sexual dimorphism involving steroidal pheromones and their binding protein in the submaxillary salivary gland of the Gottingen miniature boar. J. Endocr. 100, 195-202.

Booth, W.D. (1984b) A note on the significance of boar salivary pheromones to the male-effect on puberty attainment in gilts. Anim. Prod. 39, 149-152.

Booth, W.D. (1987) A note on the influence of a Göttingen miniature boar on puberty attainment in Large White gilts. Antim. Prod. 44, 165-168.

Booth, W.D. \& Baldwin, B.A. (1983) Changes in oestrous cyclicity following olfactory bulbectomy in postpubertal pigs. $J$. Reprod. Fert. 67, 143-150.

Booth, W.D. \& White, C.A. (1988) The isolation, purification and some properties of pheromaxein. the 
pheromonal steroid-binding protein, in porcine submaxillary glands and saliva. $J$. Endocr. 118, 47-57.

Bronson, F.H. \& Desjardins, C. (1974) Circulating concentrations of $\mathrm{FSH}, \mathrm{LH}$, estradiol and progesterone associated with acute male-induced puberty in female rats. Endocrinology 94, 1654-1668.

Bronson, F.H. \& Maruniak, J.A. (1975) Male-induced puberty in female mice: evidence for a synergistic action of social cues. Biol. Reprod. 13, 94-98.

Bronson, F.H. \& Maruniak, J.A. (1976) Differential effects of male stimuli on follicle-stimulating hormone, luteinizing hormone, and prolactin secretions in prepubertal female mice. Endocrinology 98, 1101-1108.

Brooks, P.H. \& Cole, D.J.A. (1969) The effect of boar presence on the age at puberty of gilts. Rep. Sch. Agric., Univ. of Nont. (1968-69), pp. 74-77.

Brooks, P.H. \& Cole, D.J.A. (1970) The effect of the presence of a boar on the attainment of puberty in gilts. J. Reprod. Fert. 23, 435-440.

Burnett, P.J., Walker, N. \& Kilpatrick, D.J. (1988) The effect of age and growth traits on puberty and reproductive performance in the gilt. Anim. Prod. 46, $427-436$.

Camous, S., Prunier, A. \& Peltetier, J. (1985) Plasma prolactin, LH, FSH and estrogen excretion patterns in gilts during sexual development. $J$. Anim. Sci. 60, 1308-1317.

Carpenter, L.S. \& Anderson, L.L. (1985) Pulsatile infusion of luteinizing-hormone-releasing hormone: effects on luteinizing hormone secretion and ovarian function in prepubertal gilts. Anim. Reprod. Sci. 9, 261-272.

Caton, J.S., Jesse, G.W., Day, B.N. \& Ellersieck, M.R. (1986a) The effect of confinement on days to puberty in gilts. J. Anim. Sci. 62, 1203-1209.

Caton, J.S., Jesse, G.W., Day, B.N. \& Ellersieck, M.R. (1986b) The effect of duration of boar exposure on the frequency of gilts reaching first estrus. J. Anim. Sci. 62, 1210-1214.

Christenson, R.K. (198I) Influence of confinement and season of the year on puberty and estrous activity of gilts. J. Anim. Sci. 52, 821-830.

Christenson, R.K. (1984) Influence of number of gilts per pen on estrous traits in confinement-reared gilts. Theriogenology 22, 313-320.

Christenson, R.K. (1986) Swine management to increase gilt reproductive efficiency. $J$. Anim. Sci. 63, 12801287.

Christenson, R.K. \& Ford, J.J. (1979) Puberty and estrus in confinement-reared gilts. J. Anim. Sci. 49, 743-751.

Christenson, R.K., Ford, J.J. \& Redmer, D.A. (1985) Metabolic clearance and production rates of oestradiol and progesterone during pubertal and postpubertal development in gilts. J. Reprod. Fert. 75, 247-253.

Clark, J.R., First, N.L., Chapman, A.B. \& Casida, L.E. (1970) Age at puberty in four genetic groups of swine. J. Anim. Sci. 31, 1032, abstr.

Claus, R. (1977) Boar taint: a model for male pheromone physiology. Anim. Br. Abstr. 45, 192-193 (Abstr.).

Cole, D.J.A., Dyck, G.W. \& Nathan, S. (1982) Reproduction in the gilt. 4. The effect of rearing gilts with contemporary castrated males or intact males on the attainment of puberty. Anim. Prod. 35, 171-175.
Cronin, G.M., Hemsworth, P.H., Winfield, C.G., Muller, B. \& Chamley, W.A. (1983) The incidence of, and factors associated with, failure to mate by 245 days of age in the gilt. Anim. Reprod. Sci. 5, 199-205.

Deligeorgis, S.G., Lunney, D.C. \& English, P.R. (1984) A note on efficacy of complete $v$. partial boar exposure on puberty attainment in the gilt. Anim. Prod. 39, 145-147.

Diekman, M.A. \& Hoagland, T.A. (1983) Influence of supplemental lighting during periods of increasing or decreasing daylength on the onset of puberty in gilts. J. Anim. Sci. 57, 1235-1242.

Diekman, M.A., Trout, W.E. \& Anderson, L.L. (1983) Serum profiles of LH, FSH and prolactin from 10 weeks of age until puberty in gilts. J. Anim. Sci. 56, $139-145$

Drickamer, L.C. (1987) Intermittent stimulation and acceleration of puberty by urinary chemosignals in female mice. Biol. Reprod. 37, 89-95.

Dyck, G.W. (1988) Factors influencing sexual maturation, puberty and reproductive efficiency in the gilt. Can. J. Anim. Sci. 68, I-13.

Eastham, P.R. \& Cole, D.J.A. (1987) Reproduction in the gilt. 7. Exposure of young gilts to the same mature boar and relocation: effects on the attainment of puberty. Anim. Prod. 44, 435-441.

Eastham, P.R., Dyck, G.W. \& Cole, D.J.A. (1984) Reproduction in the gilt. 5 . The effect of the presence of the mature male during rearing on puberty attainment. Anim. Prod. 39, 277-282.

Eastham, P.R., Dyck, G.W. \& Cole, D.J.A. (1986a) Reproduction in the gilt. 6 . The effect of various degrees of mature boar contact during rearing on puberty attainment. Anim. Prod. 43, 341-349.

Eastham, P.R., Dyck, G.W. \& Cole, D.J.A. (1986b) The effect of age at stimulation by relocation and first mature boar contact on the attainment of puberty in the gilt. Anim. Reprod. Sci. 12, 31-38.

Elsaesser, F. \& Smidt, D. (1986) Endokrine aspekte der steuerung von sexualentwicklung und pubertat beim schwein. Zborn. bioteh. Fak. Univ. Edvarda Kardeljav Ljubljani Kmetijssvo (Zivinoreja) 48, 261-276.

Elsaesser, F., Stickney, K. \& Foxcroft, G. (1982) A comparison of metabolic clearance rates of oestradiol$17 \beta$ in immature and peripubertal female pigs and possible implications for the onset of puberty. Acta endocr., Copenh. 100, 606-612.

Esbenshade, K.L., Paterson, A.M., Cantley, T.C. \& Day, B.N. (1982) Changes in plasma hormone concentrations associated with the onset of puberty in the gilt. J. Anim. Sci. 54, 320-324.

Fonda, E.S., Rampacek, G.B. \& Kraeling, R.R. (1984) The effect of adrenocorticotropin or hydrocortisone on serum luteinizing hormone concentrations after adrenalectomy and/or ovariectomy in the prepubertal gilt. Endocrinology 114, 268-273.

Ford, J.J. \& Teague, H.S. (1978) Effect of floor space restriction on age at puberty in gilts and on performance of barrows and gilts. J. Anim. Sci. 47, 828-832.

Foxcroft, G.R. \& van de Wiel, D.F.M. (1982) Endocrine control of the oestrous cycle. In Control of Pig Reproduction, pp. 161-178. Eds D. J. A. Cole \& G. R. Foxcroft. Butterworths, London.

Grumbach, M.M., Roth, J.C., Kaplan, S.L. \& Kelch, R.P. (1974) Hypothalamic-pituitary regulation of puberty 
in man: evidence and concepts derived from clinical research. In Control of the Onset of Puberty, pp. 115-186. Eds M. M. Grumbach, G. D. Grave \& F. E. Mayer. John Wilcy \& Sons, New York.

Hemsworth, P.H. \& Barnett, J.L. (1990) Behavioural responses affecting gilt and sow reproduction. $J$. Reprod. Fert., Suppl. 40, 343-354.

Hemsworth, P.H., Barnett, J.L., Hansen, C. \& Winfield, C.G. (1986) Effects of social environment on welfare status and scxual behaviour of female pigs. II. Effects of space allowance. Appl. Anim. Behav. Sci. 16, 259-267.

Hemsworth, P.H., Hansen, C., Winfield, C.G. \& Barnett, J.L. (1988) Effects on puberty attainment in gilts of continuous or limited exposure to boars. Aust. J. exp. Agric. 28, 469-472.

Huff, B.G. \& Esbenshade, K.L. (1988) Response of prepubertal gilts to hourly administration of luteinizing hormone (LH). J. Anim. Sci. 66 (Suppl. 1), 395, abstr.

Hughes, P.E. (1982) Factors affecting the natural attainment of puberty in the gilt. In Control of Pig Reproduction, pp. 117-138. Eds D. J. A. Cole \& G. R. Foxcroft. Butterworths, London.

Hutchens, L.K., Hintz, R.L. \& Johnson, R.K. (1982) Breed comparisons for age and weight al puberty in gilts. J. Anim. Sci. 55, 60-66.

Karlbom, I. (1981/2) Attainment of puberty in female pigs: influence of boar stimulation. Anim. Reprod. Sci. 4, 313-319.

Karlbom, 1., Einarsson, S. \& Edqvist, L.-E. (1981/2) Attainment of puberty in female pigs: clinical appearance and patterns of progesterone, oestradiol-17 $\beta$ and LH. Anim. Reprod. Sci. 4, 301-312.

Killian, D.B., Kiesling, D.O. \& Jones, B.L. (1983) Estrus and ovulation induced in adrenalectomized and intact prepubertal crossbred gilts using pregnant mare serum gonadolropin (PMSG) and human gonadotropin (HCG). J. Anim. Sci. 55 (Suppl. 1), 103, abstr.

Killian, D.B., Kiesling, D.O., Wulf, F.P. \& Stewart, A.N.V. (1987) Effects of adrenalectomy and glucocorticoids on puberty in gilts reared in confinement. J. Anim. Sci. 64, 231-236.

King, R.H. (1989) Effect of live weight and body composition of gilts at 24 weeks of age on subsequent reproductive efficiency. Anim. Prod. 49, 109-116.

Kinsey, R.E., Carlson, R., Proud, C. \& Zimmerman, D.R. (1976) Influence of boar component stimuli on age at puberty in gilts. J. Anim. Sci. 42, 1362, abstr.

Kirkwood, R.N. (1980) Puberty in the gilt. Ph.D. thesis, University of Leeds.

Kirkwood, R.N. \& Hughes, P.E. (1979) The influence of age at first boar contact on puberty attainment in the gilt. Anim. Prod. 29, 231-238.

Kirkwood, R.N. \& Hughes, P.E. (1980a) A note on the efficacy of continuous $v$. limited boar exposure on puberty attainment in the gilt. Anim. Prod. 31, 205-207.

Kirkwood, R.N. \& Hughes, P.E. (1980b) A note on the influence of 'boar effect' component stimuli on puberty attainment in the gilt. Anim. Prod. 31, 209-211.

Kirkwood, R.N. \& Hughes, P.E. (1981) A note on the influence of boar age on its ability to advance puberty in the gilt. Anim. Prod. 32, $211-213$.

Kirkwood, R.N., Forbes, J.M. \& Hughes, P.E. (1981) Influence of boar contact on attainment of puberty in gilts after removal of the olfactory bulbs. J. Reprod. Fert. 61, 193-196.

Kirkwood, R.N., Hughes, P.E. \& Booth, W.D. (1983) The influence of boar-related odours on puberty attainment in gilts. Anim. Prod. 36, 131-136.

Li, P.S. (1987) The effects of cortisol and ACTH on LH secretion by pig pituitary cells in vitro. Biol. Reprod. 36, 119 , abstr.

Lutz, J.B., Rampacek, G.B., Kraeling, R.R. \& Pinkert, C.A. (1984) Serum luteinizing hormone and estrogen profiles before puberty in the gilt. J. Anim. Sci. 58, 686-691.

Lutz, J.B., Rampacek, G.B. \& Kraeling, R.R. (1985) Induction of ovulation in the prepubertal gilt by pulsatile administration of gonadotrophin releasing hormone. Dom. Anim. Endocr. 2, 61-65.

Martin, C.B., Oldham, C.M. \& Lindsay, D.R. (1980) Increased plasma LH levels in seasonally anovular Merino ewes following the introduction of rams. Anim. Reprod. Sci. 3, 125-132.

Mavrogenis, A.P. \& Robison, O.W. (1976) Factors affecting puberty in swine. J. Anim. Sci. 42, 1251-1255.

Meijs-Roelofs, H.M.A., Kramer, P. \& Sander, H.J. (I983) Changes in serum concentration of luteinizing hormone in the female rat approaching puberty. $J$. Endocr. 98, 241-249.

Narendran, R., Etches, R.J., Hurnik, J.F. \& Bowman, G.M. (1980) Effect of social hierarchy on plasma 5 androstenone levels in boars. Can. J. A $\mathrm{nim}$. Sci. 60, 1061, abstr.

Paterson, A.M. (1982) The controlled induction of puberty. In Control of Pig Reproduction, pp. 139-159. Eds D. J. A. Cole \& G. R. Foxcroft. Butterworths. London.

Paterson, A.M. \& Lindsay, D.R. (1980) Induction of puberty in gilts. 1 . The cffects of rearing conditions on reproductive performance and response to mature boars after early puberty. Anim. Prod. 31, 291-297.

Paterson, A.M. \& Lindsay, D.R. (198I) Induction of puberty in gilts. 2. The effect of boars on maintenance of cyclic activity in gilss induced to ovulate with pregnant mares serum gonadotrophin and human chorionic gonadotrophin. Anim. Prod. 32, 5I-54.

Paterson, A.M., Cantley, T.C. \& Day, B.N. (1980) Plasma estradiol and $\mathrm{LH}$ in prepubertal gilts relocated and exposed to a boar. J. Anim. Sci. 51 (Suppl. I.), 315 abstr.

Paterson, A.M., Hughes, P.E. \& Pearce, G.P. (1989a) The effect of limiting the number of days of contact with boars, season and herd of origin on the altainment of puberty in gilts. Anim. Reprod. Sci. 18, 293-301.

Paterson, A.M., Hughes, P.E. \& Pearce, G.P. (1989b) The effect of season, frequency and duration of contact with boars on the attainment of puberty in gilts. Anim. Reprod. Sci. (in press)

Pearce, G.P. (1982) Aspects of puberty induction in the gilt. B.Sc. thesis, University of Noltingham.

Pearce, G.P. \& Hughes, P.E. (1985) The influence of daily movement of gilts and the environment in which boar exposure occurs on the efficacy of boarinduced precocious puberty in the gilt. Anim. Prod. 40, 161-167.

Pearce, G.P. \& Hughes, P.E. (1987a) The influence of male contact on plasma cortisol concent rations in the prepubertal gilt. J. Reprod. Fert. 80, 417-424. 
Pearce, G.P. \& Hughes, P.E. (1987b) The influence of boar-component stimuli on puberty attainment in the gilt. Anim. Prod. 44, 293-302.

Pearce, G.P., Hughes, P.E. \& Booth, W.D. (1988) The involvement of boar submaxillary salivary gland secretions in boar-induced precocious puberty attainment in the gilt. Anim. Reprod. Sci. 16, 125-134.

Pearce, G.P., Paterson, A.M. \& Hughes, P.E. (1988) Effects of short-term elevations in plasma cortisol concentration on LH secretion in prepubertal gilts. $J$. Reprod. Fert. 83, 413-418.

Perry, G.C., Patterson, R.L.S., MacFie, H.J.H. \& Stinson, C.G. (1980) Pig courtship behaviour: pheromonal property of androstene steroids in male submaxillary secretions. Anim. Prod. 31, 191-199.

Poindron, P., Cognie, Y., Gayerie, F., Orgeur, P., Otdham, C.M. \& Ravault, J.P. (1980) Changes in gonadotrophin and prolactin levels in isolated (seasonally or lactationally) anovular ewes associated with ovulation caused by introduction of rams. Physiol. Behav. 25, 227-236.

Ramirez, V.D. \& McCann, S.M. (1963) Comparison of the regulation of luteinizing hormone $(\mathrm{LH})$ secretion in immature and adult rats. Endocrinology 72, $452-464$.

Rampacek, G.B., Kraeling, R.R. \& Kiser, T.E. (1981) Delayed puberty in gilts in total confinement. Theriogenology 15, 491-499.

Reed, H.C.B., Melrose, D.R. \& Patterson, R.L.S. (1974) Androgen steroids as an aid to the detection. of oestrus in pig artificial insemination. Br. vet. J. 130, 61-67.

Scheimann, C.A., England, D.C. \& Kennick, W.H. (1976) Initiating estrus in prepubertal confinement gilts. $J$. Anim. Sci. 43, 210, abstr.

Smith-White, S. \& Ojeda, S.R. (1981) Changes in ovarian LHRH receptor content during the onset of puberty in the female rat. Endocrinology 108, 347-349.

Suzuki, K., Kawakura, K. \& Tamaoki, B.I. (1978) Eflects of pregnant mare's serum gonadotrophin on the activities of $\Delta^{4}$-5a-reductase, aromatase and other enzymes in the ovaries in immature rats. Endocrinology 102, 1595-1605.

Vangen, O. (1986) Genetic control of reproduction and lactation in non-ruminants. Postnatal survival, puberty and rebreeding interval. In Proc. 3rd W/d Congr. Genetics Applied to Livestock Production, Nebraska.

Van Lunen, T.A. \& Aherne, F.X. (1987) Influence of method of boar exposure on age at puberty gilts. Can. J. Anim. Sci. 67, 553-556.

Wodzicka-Tomaszewska, M., Martinat-Botte, F., Prunier, A. \& Signoret, J.P. (1985) Effects respectif́s de la mise en presence du male et du stress sur le declenchement de la puberte de la jeune truie. Journees rech. porcine en France 17, 139-146.

Zimmerman, D.R. \& Kopf, J.D. (1986) Age at puberty in gilts as affected by boar maturity, type of boar exposure and age of gilts when boar exposure is initiated. J., Animi. Sci. 63 (Suppl. 1), 355, abstr. 